\title{
Pancasila as a Scientific Paradigm for Studying Legal Pluralism in Indonesia: a Literary Perspective
}

\author{
Sudjito $^{1, *}$, and Tatit Hariyanti ${ }^{2}$ \\ ${ }^{1}$ Faculty of Law Gadjah Mada University, 55281, Indonesia \\ ${ }^{2}$ Faculty of Humanities, University of Technology Yogyakarta, 55285, Indonesia
}

\begin{abstract}
There has not been a common ground for perception of legal pluralism in Indonesia. Pros and cons against it are still found, both on the theoretical and practical levels. It is often opposed by legal unification which might endanger the unity of nation. Under the movement of law and literature, this paper is intended to promote the contribution of literature to share the common ground for the study of legal pluralism in Indonesia. Using the literary point of view, legal products is analogous to literary products. A study of literary works will not be separated from the paradigm applied. One paradigm used is that the study of literary works will be inseparable from the reality that exists in society. The study of legal pluralism can be analogous to the study of various works of literature. The issue of pluralism and national law needs to be studied based on a deeply rooted value system in the life of the Indonesian nation, Pancasila. In a literary perspective, Pancasila deserves to be a scientific paradigm for studying legal pluralism in Indonesia. The values of Pancasila are believed to be true, and are used as guidelines in all activities of Indonesian life.
\end{abstract}

\section{Introduction}

The study of legal pluralism is still a polemic in Indonesia. There have been various conflicting arguments as to whether it is acceptable or not and whether it is dangerous or not for the existence of national law and the unity of nation. Each party has its own argument based on his own perspective. There are some interesting facts dealing with the study of legal pluralism. First, legal pluralism presents as a criticism toward centralism and positivism of the application of law to the people. There are various perspectives in understanding legal pluralism. (1) Legal pluralism explains the relation of various legal systems applying in society. (2) Legal pluralism maps the various laws that exist in a social field. (3) Legal pluralism explains relationships, adaptations, and competitions among the legal systems. (4) Legal pluralism exposes people's choice to use certain laws when they are in conflict. Those perspectives thus demonstrate the fact that the legal pluralism exists in the society. Referring to Tamanaha legal pluralism is everywhere [1],[2].

\footnotetext{
*Corresponding author: sudjito_fh_ugm@yahoo.com
} 
However, the interesting part of legal pluralism lies not only on the diversity of its normative systems but foremost on the fact of conflict potentials among the existing systems that gives rise to the uncertainty. This uncertainty becomes one of the weak points to attack legal pluralism, although this is not entirely true because the main issue of conflict potential is the existence of asymmetric relations of the normative system. In this respect, John Griffiths puts forward the concept of weak pluralism and strong pluralism [3]. Legal pluralism is weak when the state acknowledges the existence of non-state normative orders but ignoring their enforceability. Non-state legal systems are subject to their enforceability under state law. Legal pluralism is strong when the state acknowledges the existence of non-state legal systems and its enforceability as well.

The thoughts of Tamanaha and Griffiths lead us to the study of the weakness of legal pluralism and criticism toward legal pluralism. There are two things to highlight. First, when the imbalance of power dominance among the exponents of various legal systems remains sustainable, then legal pluralism may turn to be a myth or delusion. Second, the creation of legal uncertainty is not impossible if legal pluralism opens the confessional space for any other legal system outside the law of the country without any clear limitation. These remind us that legal pluralism which is initially adopted to criticize might be the object of criticism.

Second, there is a tendency to study and practice legal pluralism using partial, dichotomous, mutually exclusive perspectives, even put it as the system opposing with legal unification as the representation of national law. As a result, between the two, there is competition for victory, strengthening legality, legitimacy, and domination, instantly ignoring the existence of others. Empirically, national law, as a form of unification of law emerges victorious, while religious law, customary law, as well as local law, as a representation of legal pluralism increasingly marginalized. In situations of such competition, religious law, customary law, and local law, are in a dying condition.

Third, the partial perspective above does not appear instantly, rather it is part of the history of the Indonesian nation. It is believed that such a reality also occurs in countries formed on various ethnic groups with its cultural diversity. Differences in understanding of legal pluralism often lead to horizontal and vertical conflicts. The disharmony of the laws of the people and the state arises as a result of the national law development policy which transplants 'foreign' laws in various ways to the people who actually have their own laws. The word 'foreign' in this case can be interpreted in two senses, on the one hand 'foreign' can be sourced from colonial law applied in the colony, and on the other hand the 'foreign' law is a national law which becomes the product of unification and the modernization of the law, both of which directly or indirectly exclude the diversity of people's laws or elements of the legal system existing outside the state / national legal system [4].

Fourth, at the empirical level, the enactment of ideologically and unconstitutionally defective regulations, in many cases harm the people, but instantly giving many advantages for a handful of officials, rulers, and employers. Social injustice in the field of natural resources and in the social-religious field becomes a reality everywhere. Natural resource conflicts, and religious conflict, or Tribes, Races, Religions, And Intergroup, (SARA) nuances - both horizontal and vertical conflicts - continue to increase, both quantitatively and qualitatively. Is not such a thing, contrary to Article 33 paragraph (3) of the 1945 Constitution that the earth, water, space and natural resources contained therein are controlled by the state and used for the greatest prosperity of the people? Instead of promising prosperity, it causes the inner-hearted suffering.

Fifth, the fierce debate between legal unification and legal pluralism has been going on since the Dutch colonial era. However, until now it has not been successfully completed. For adherents to legal unification, the integrated national law is needed to abolish legal pluralism [5]. Indeed, the emergence of legal pluralism movements is often seen as a 
strengthening of tribalism and weakening the spirit of nationalism. Legal Pluralism is a reality. National law as an idea, in the legal terminology of law is still ius constitendum. It is expected to become a concrete reality as tangible as ius constitutum. The transformation of reality has not been easily realized. However there has been great attempt to do so. Through the process of legislation, existence, and relationships between various entities are in the process of proper formulation. At this stage ideas from various parties are worth listening to.

Those problems happen because that there has not been a common ground for the legal pluralism's study, while, it ironically endangers the unity of nation. This invites great concern not only from those who deal directly with the legal matters such as law students, practitioners and legal scientists but also those who are interested in legal matters from different field of studies. The problem requires a fundamentally new way of thinking. Legal pluralism should not be stigmatized as the opponent to the spirit of nationalism and national law. The study of legal pluralism should not be meant to isolate religious law, customary law, or local law, from the national arena, but rather placing it within the framework of Indonesian unity. Under the movement of law and literature, this study tries to deal with it. In a literary perspective there should be a new paradigm as the common ground for the study of legal pluralism in Indonesia. It is not necessarily completely new. It may be derived from the existing one, the old or neglected one, tangible or intangible one. Pancasila deserves to be a scientific paradigm in studying legal pluralism in Indonesia.

\section{Theoretical frameworks}

Law and Literature movement has been developing in western countries since the first half of the twentieth century as the response of the isolation of law from other disciplines and the idea of humanizing law to have optimal function for the betterment of social order. In its early stages this movement focused strictly on the law in literature; however, starting from the late 1970s the law as literature perspective has been gaining its popularity. The notion of the law as literature draws insights from literary criticisms and theories in assisting the reading and the interpretation of legal text [6]. Legal texts can be analogue to literary works. Theoretically there are at least four major paradigms in studying literary works. The first paradigm requires the sole attention to the works itself and the others require to connect the works with the makers, the readers and the universe. To serve the best function the works have to be connected with the makers, the users and the dynamic reality in society as the object. The synergy of three factors outside of the work itself [7] will give rise to the optimal function of the work. In creating the work the author need to consider the interest of the audience and to do so he should take great consideration of what happened in society.

"The significance of the literary works cannot be fixed solely by the intention of the author but also by its acceptance and the usefulness for the society; and to be able to do so the author needs to be attentive to what happens in the society and take it as the subject-matter for the betterment of society" [7].

Similarly the study of legal pluralism can be done by the same paradigms applied in Literature. Various legal systems can be analogue to various literary texts and genres. They will be accepted and function well if they are significantly rooted in society. The basic ground needs to be found from their lives. Pancasila as a value system has long been the way of life of the nation. The value system has been formulated into the Philosophische Grondslag, and a source in making state law. In a scientific perspective, Pancasila is the 
paradigm of Indonesian science and it deserves to be the common ground for the study of legal pluralism in Indonesia.

\section{Discussion}

The study begins with understanding, actualizing and affirming the relationship between Pancasila, legal pluralism, and national law as well. Etymologically, the word "plural" means more than one. From this root word come the word "pluralism", means: the thing that says plural or not one. For example: "cultural pluralism", means different cultures in a society [8]. Here, legal pluralism is defined as the diversity of the law. Legal pluralism refers to the existence of differing legal systems in a population or area.

With regard to plurality, there is a word "bhinneka" which means different or diverse. The word "bhinneka" is used typically in Indonesia, and is coupled with the words "Tunggal Ika" so that it reads "Bhinneka Tunggal Ika" which linguistically means diverse, but one and commonly refers to "Unity in Diversity." This series of words is the motto of the state, with the aim of explaining the ideology of the Indonesian nation, namely Pancasila. The existence of the motto is, firmly attached, united on the symbol of the State, the eagle. The motto is inscribed on a ribbon gripped by both feet. From the sentence it is also implied about the soul and spirit of diversity of tribes, religions, languages and various other aspects of culture in Indonesia. Diversity is interpreted not as differences that are worthy of contradiction with one another, but to the facts the strength of which is needed to be dug to obtain its grace, so that all components of the nation remain united in the container Indonesia-ness [8].

In an ideological perspective, if the problem of pluralism is viewed from the 1 st principle - Belief in the One Supreme - it would seem that in pluralism it contains religious values. These values are found in the religions that exist in Indonesia. Islam, for example, teaches its people about the meaning of diversity, in order to get to know each other.

Allah Almighty says:

"O mankind, indeed We have created you from male and female and made you peoples and tribes that you may know one another. Indeed, the most noble of you in the sight of Allah is the most righteous of you. Indeed, Allah is Knowing and Acquainted. "(QS, 49: 13) [9].

The meaning of knowing one another in diversity goes far beyond what is called tolerance. Tolerance is a mutual respect between groups, or between individuals, accompanied by efforts to keep away from discrimination. The culmination of the meaning of knowing one another in diversity is god-fearing (taqwa). The Implementation of Unity in Diversity should arrive at such a degree of devotion.

The stronger the understanding of the meaning of diversity in a person, or a tribe, or group, the more likely it is for the person, the tribe, or the group to contribute to bringing about a common peace. From knowing each other it can be drawn lessons and experiences of others, in order to increase levels of devotion (ketaqwaan) respectively [10].

The starting point of the study of legal pluralism and national law should be always based on the spiritual values contained in the national slogan. This is so important, because the slogan is not just empty words without meaning, but becomes part of a unity with the state symbol, namely Garuda Pancasila.

Pancasila was originally the way of life of the nation, which then is formulated by founding fathers into Philosophische Grondslag. And, it should not be forgotten that Pancasila by Notonagoro [11] referred to as the source of science, or in the terminology of Thomas Kuhn (1962) called the paradigm of science [12]. 
Pancasila as a way of life has existed since hundreds of years ago, long before Indonesia became independent. The values of Pancasila are deeply rooted in the three realms of life: they are in customs, cultures, and religions. That is the materialist cause of Pancasila [13].

From the speech of Bung Karno in front of the East Java people's congress, September 24, 1955 in Surabaya, it is known that Pancasila as the five brightest pearls, immersed in the Indonesian earth due to foreign colonization for 350 years. Bung Karno is not the creator of Pancasila, but one of his diggers, and then after it has been dug up dedicated to the Indonesian nation. He said:

"Pancasila, as a way of life has already existed before Bung Karno comes into being, Pancasila has existed before there is Republic of Indonesia. From the beginning, the Indonesian people had known God and lived in the Divine Nature of the One Supreme God. From the first, the nation of Indonesia has love to the homeland and nation. From the first, we already know the sense of nationality and sense of humanity, as well as the sense of popular sovereignty and the ideals of social justice. The Indonesian nation is the only nation that never colonizes other nations" [14].

Implicitly positioning and practicing Pancasila as a way of life, implies a moral message that for any law-makers or policy makers who are in the process of making the laws, they should be always oriented towards the achievement of the objectives of the State. The entire law of the state must pay attention to the dimensions of nationality, the integrity of the territory of the homeland, the general welfare, the intellectual life of the nation, and contribute to the international world for the achievement of order, freedom, peace and social justice.

As such, it should be viewed as a composite system, composed of components of body, mind, spiritual, interrelated, spiritual, social-ecological, national-international material hanging. The dimension of unity becomes very central and important to note [15].

"Unity" becomes the key words for the realization of happiness. David Bohm, in his book "Health and The Implicate Order" [16], gives enlightenment that the word health comes from the word whole. A person will recover from illness, being healthy and happy when his/ her whole life is in unity. The whole life includes: the self, as a social being, as an environmental being, as a nation, as a citizen of the world, even as the deputy of God (khalifatullah) on earth. The formulation of state objectives in the Preamble of the 1945 Constitution has included the integrity of life.

For the purpose of the state to be easily achieved, the founding fathers have given provision for the next generation: (1) Pancasila as Philosophische Grondslag, and (2) Preamble to the 1945 Constitution as Staatsfundamentalnorm. Both have a permanent, strong and unchanging nature and position, attached to the survival of the state, and in the hierarchy of Indonesian law it is at the highest position and becomes the source of the law for the articles of the Constitution as well as other laws under it.

Therefore, in order for this nation to be happy, the substance of the articles of the Constitution, the Assembly of the People's Consultative Assembly, the Law and various other laws and regulations, should be made in the context of realizing the objectives of the state. Legal pluralism must also be studied and placed appropriately within the framework of Pancasila as the Philosophical Grondslag and Staatsfundamentalnorm.

In the perspective of Pancasila as a scientific paradigm, all conducts must be the basis of science. Science itself is not value-free, it is full of values. Toward the Indonesian nation, at the level of philosophy of science, its axiology and teleology is Pancasila.

Science as an institution of truth-seeking is a continuously growing institution. The development must certainly lead to truth and absolute justice. It should be realized that the truth and absolute justice is only in the God Almighty, so the development of science needs 
to be directed to the truth and the absolute justice. In the context of Indonesian life, placing God Almighty as a source, as well as direction, and goal of science, is a scientific activity commonly called Pancasila paradigm. Such mentioning is none other than because the First precepts are the God Almighty, and further the First precepts include and animate the other underlying precepts as a whole.

Pancasila as a scientific paradigm becomes very important and therefore needs to be strengthened for three reasons. First, the paradigm is "a set of values (about God, nature and man, and the relationship between the three), which is believed to be true and the laws and application techniques shared by members of a scientific community"; Second, Paradigm is the source, foundation, origin and beginning of existence and development of science; and Third, in the Symposium and Workshop on Pancasila at UGM in the middle of 2006 and National Seminar on The Values of Pancasila at Pancasila University Jakarta in late 2006, it has been believed that the paradigm of Indonesian science is Pancasila. That is, to study and practice science, it should be centralized, processed and derived from the values of Pancasila.

The founding fathers have succeeded in exploring the values of Pancasila, and then crystallized them into the Basic State formula. Thus, it is inevitable to make Pancasila as the paradigm of Indonesian science, because the values of Pancasila have been believed to be true, and used as a guideline in all activities of life.

It can be said that Pancasila-based science is a category of science typical of Indonesia, but objectively universal. This science is pivoted from God Almighty. It is loaded with the values of the Believers of the Almighty and other values in the frame of God's Supreme value.

Pancasila-based science for the nation of Indonesia is a gift. This science reached the nation of Indonesia through the teachings of religion. Based on the teachings of religion, the study of truth and justice is always in the perspective of the God. Understanding of Devine values, not on the basis of dogma, but on the basis of common sense (rational). Indonesian people always use their minds to think to be able to understand the nature of God, nature and man. The results of thought that's what gave birth to philosophy. Based on the truth and philosophical justice, it will appear the ideas of the Indonesian people about the best life in the future.

A typical Indonesian ideology is an ideology rooted in the value of Pancasila. From this ideology it emerged various theories, as a means to explain and predict the entire reality of life of the nation. To explain the reality of the life of a nation, a methodology is needed. The specificity of Indonesia's science methodology lies in the object of cultivation, the method of cultivation, and the purpose of cultivation. A holistic approach to reality - both inner and inner aspects, essence and existence, symbolic or meaningful - is necessary, so that no part of the object of science is missed. Anomalies of social-state life that fail to be resolved by conventional science will be solved by the science of Pancasila paradigm. Science of Indonesia as it is said to be true and beneficial to the life of this world-the hereafter.

When the Indonesian people are faced with the complexity of legal issues - whether they regulate population, religion, land, and other SARA issues - the debate on collectivism and individualism is inevitable. For the adherents of collectivism, religious law, customary law, or local law, ideologically is best regarded as the basis of national law. This is not only because religious law, customary law, or local law, is the origin of the original law of the Indonesian nation, but also because of its communal-religious character, in harmony with the character of the Indonesian nation.

Since Indonesia became independent, the division of population groups was abolished, and the only difference being that of citizens or non-citizens. For Indonesian citizens, it is not questioned, whether they are indigenous people or not, male or female. Population 
policy that leads to unity of law, unification, and uniformity is not yet deserved to be seen as progress, because in a heterogeneous society there is always encountered disparity. It thus indicates that legal pluralism is still needed, and not easily replaced by legal unification.

The change of society from traditional-collectivistic to modern-individualistic perhaps has become part of the will of the age. In such social change, legal pluralism tends to be less competitive than legal unification. As long as legal politics adheres to the superior pareto principle that is oriented to the welfare of employers and rulers, while at the same time putting aside the optimal pareto principle of building without the suffering of the people, legal pluralism will lose against the unification of state law. The urgency of Pancasila as a scientific paradigm needs to really get attention, so on the one hand the study of legal pluralism is not biased to other ideologies, and on the other hand the development of national legal system can be organized based on the values of Pancasila.

\section{Conclusion}

Contestation between legal pluralism and legal unification needs to be terminated. Unity between the two needs to be realized. It is the time for Indonesian to adopt holistic perspective as the replacement of partial perspective. Under the movement of law and literature, the study of legal pluralism can be analogous to the study of various works of literature. The issue of pluralism and national law needs to be studied based on a deeply rooted value system in the life of the Indonesian nation, Pancasila.

Understanding of the plurality of laws, followed by the study of the values of Pancasila, will in turn produce a wealth of jurisprudence and practices of large-scale, outerworld, the hereafter. Legal pluralism should be accepted sincerely by all components of the nation, and there is a commitment to strengthen religious law, customary law, and local law. Acceptance of legal pluralism needs to be balanced with the protection of the rights of the people. The protection of the law should be systemic and normative, so that although the concept of legal pluralism is weak, social justice can be widely disseminated and comprehensive.

The unity among all components of the nation should be actualized against neocolonialism in the era of globalization. In fact, almost all components of the nation are caught up in liberal-individualistic ideals, tend to be hedonistic-materialistic, and forget the ideology of Pancasila. Therefore, actualizing Pancasila as the way of life, Philosophische Grondslag and as a scientific paradigm is essential for legal pluralism and legal unification to be in wholeness.

Legal pluralism may contribute to the realization of national unity, if the method of study is holistic. National law should be studied as a whole, complex and dynamic reality. That's where legal pluralism can prove itself as a useful science to unite the Indonesian nation.

\section{References}

1. B. Z. Tamanaha, Syd LR. 30, 378

2. M. Colchester, S. Chao, ed, Beragam Jalur Menuju Keadilan:Pluralisme Hukum dan Hak-Hak Masyarakat Adat di Asia Tenggara (Epistema Institute, Jakarta, 2012)

3. J. Griffiths, J Legal Pluralism \& Unofficial, 24, 1-55 (1986)

4. M. A. Safitri (Ed), Untuk Apa Pluralisme Hukum?: Konsep, Regulasi, Negosiasi dalam Konflik Agraria di Indonesia (Epistema Institut, Jakarta, 2011)

5. T. Prasetyo, J. H. P. 3, 222 (2014) 
6. C. R. B. Dunlop, Cardozo Stud L \& Lit. 3, 63 (1991)

7. T. Hariyanti. J. Humaniora, 25, 119 (2013)

8. Ministry of Education and Culture, (Balai Pustaka, Kamus Besar Indonesia, Jakarta, 1990)

9. https://quran.com/49/13

10. S. Atmoredjo, Langkanya Kedamaian, (Koran Sindo, Jakarta, 2018)

11. Notonagoro. Pancasila Secara Ilmiah Populer, (Bhumi Aksara, Jakarta, 1971)

12. T. Kuhn. The Structure of Scientific Revolution. (University of Chicago Press, Chicago, 1962)

13. Notonagoro, Pancasila basic Philosophy of the Republic of Indonesia, Speech on the conferment of Doctor Honoris Causa to President RI Ir.Soekarno, at UGM, Yogyakarta, 1951

14. Sudjito, Student as Pancasila Warrior, Paper for National Seminar of Pancasila with theme "Pancasila Values Culture for Young Generation", May 10, 2014

15. Sudjito. Pertautan Politik dan Hukum, (Koran Sindo, Jakarta, 2014)

16. D. Bohm. Wholeness and the Implicate Order, (Ark Paperbacks, London, 1980) 